12,09

\title{
Физико-химические свойства и антиоксидантная активность наночастиц оксида церия, стабилизированных мальтодекстрином
}

\author{
(C) С.А. Маслова ${ }^{1,2}$, И.Н. Бажукова ${ }^{1}$, А.В. Мышкина ${ }^{1}$, Е.О. Бакшеев ${ }^{1}$, \\ М.О. Пронина ${ }^{1}$, М.А. Машковцев ${ }^{1}$, А.С. Фарленков ${ }^{3}$ \\ ${ }^{1}$ Уральский федеральный университет, \\ Екатеринбург, Россия \\ ${ }^{2}$ Институт фоизики металлов УрО РАН, \\ Екатеринбург, Россия \\ ${ }^{3}$ Институт высокотемпературной электрохимии УрО РАН, \\ Екатеринбург, Россия \\ E-mail: i.n.sedunova@urfu.ru
}

Поступила в Редакцию 8 июля 2021 г.

В окончательной редакции 13 июля 2021 г.

Принята к публикации 16 июля 2021 г.

Выполнено исследование физико-химических свойств наночастиц оксида церия в мальтодекстриновой оболочке. Были исследованы структура поверхности и свойства наночастиц $\mathrm{CeO}_{2}$, показана их способность выполнять функции ферментов каталазы и пероксидазы, а также инактивировать гидроксильные радикалы.

Ключевые слова: наночастицы, оксид церия, каталитическая активность, антиоксидантная активность.

DOI: $10.21883 /$ FTT.2021.12.51660.20s

\section{1. Введение}

Наночастицы оксида церия $\mathrm{CeO}_{2}$ представляют собой перспективный объект для применения в медицине и биологии. В основе медико-биологического применения наночастиц лежит присущая им высокая кислородная нестехиометрия, обусловливающая проявляемую ими биологическую активность, а также отсутствие токсичности в живых системах [1-3]. Наличие смешанных валентных состояний и кислородных вакансий на поверхности данных наночастиц влияет на их способность участвовать в окислительновосстановительных процессах в клетке и проявлять каталитическую, антиоксидантную и другие виды биологической активности.

Высокая биологическая активность нанокристаллического оксида церия связана, в первую очередь, со строением его кристаллической решетки. Церий - редкоземельный металл из группы лантаноидов, проявляющий степени окисления +3 и +4 , соответствующие оксиды церия - $\mathrm{Ce}_{2} \mathrm{O}_{3}$ и $\mathrm{CeO}_{2}$. Кристаллическая решетка оксида церия $\mathrm{CeO}_{2}$ представляет собой кубическую гранецентрированную решетку, каждый атом кислорода расположен в центре тетраэдра, вершинами которого являются четыре атома церия. С уменьшением размеров частиц, в отличие от многих веществ, для оксида церия наблюдается увеличение параметра элементарной ячейки кристаллической решетки. При переходе в нанокристаллическое состояние поверхностный атом кислорода покидает решетку и оставляет два электрона, которые локализуются во внутренней оболочке двух ближайших атомов церия, осуществляя переход из $\mathrm{Ce}^{4+}{ }_{\text {в }} \mathrm{Ce}^{3+}[4]$.
Ионный радиус $\mathrm{Ce}^{3+}(0.1143 \AA)$ больше ионного радиуса $\mathrm{Ce}^{4+}(0.097 \AA)$, что объясняет расширение кристаллической решетки.

Таким образом, образование кислородных вакансий в структуре нанокристаллического оксида церия $\mathrm{CeO}_{2}$ ведет к повышению доли атомов $\mathrm{Ce}^{3+}$ на поверхности частиц и увеличению кислородной нестехиометрии. Нанокристаллический оксид церия представляет собой структуру „ядро в оболочке“, где ядром является близкий к стехиометричному оксид церия $\mathrm{CeO}_{2}$, а поверхность близка по составу к $\mathrm{Ce}_{2} \mathrm{O}_{3}$. Иными словами, кислородная нестехиометрия увеличивается от центра к периферии [5]. Такая структура обусловливает активность наночастиц оксида церия в окислительно-восстановительных процессах. Благодаря высокой кислородной нестехиометрии наночастицы способны связывать реакционные кислородсодержашие соединения и радикалы, губительные для живых систем. В ряде работ продемонстрировано, что наночастицы $\mathrm{CeO}_{2}$ проявляют мультиферментативную активность, выполняя функции различных ферментов: супероксиддисмутазы, каталазы, пероксидазы, оксидазы [1,5-7].

Эффективность использования наночастиц $\mathrm{CeO}_{2}$ в медицине в значительной степени зависит от метода и условий их синтеза, поскольку именно они определяют размер, морфологию и физико-химические свойства наночастиц, а, следовательно, и их биологическую активность. Кроме того, используемые при синтезе прекурсоры и стабилизаторы могут влиять на биосовместимость наночастиц и их токсичность в живых системах. Поэтому при выборе метода синте- 
за наночастиц для медицинского применения необходимо одновременно учитывать множество факторов, влияющих на свойства наночастиц, их активность и поведение в биологических системах. Поскольку для применения наночастиц в биомедицинской практике необходимы их стабильные агрегативно-устойчивые золи [8], то при их синтезе используют различные добавки или покрытия, позволяющие увеличить растворимость и устойчивость коллоидных растворов наночастиц. В качестве стабилизаторов при синтезе чаще всего используют вещества, способные адсорбироваться на поверхности наночастиц, или органические соединения, выполняющие роль каркаса, между элементами которого располагаются наночастицы. Одними из наиболее перспективных материалов для стабилизации наночастиц являются низкомолекулярные глюканы, содержащие 2-20 структурных элементов в цепи [9]. Интерес к использованию данных материалов связан с тем, что биополимерные молекулы способны одновременно контролировать размеры получаемых наночастиц в процессе синтеза и выступать в качестве коллоидных стабилизаторов высокодисперсных золей наночастиц. При этом, отмечается, что окислительновосстановительные свойства наночастиц $\mathrm{CeO}_{2}$, стабилизированных полисахаридными молекулами, полностью сохраняются [10]. К настоящему времени известны технологии синтеза наночастиц $\mathrm{CeO}_{2}$ в следующих биополимерных оболочках: декстран, поллулан, крахмал, хитозан и т. п. [11].

Однако имеются лишь фрагментарные литературные данные по исследованию физико-химических свойств и антиоксидантной активности наночастиц $\mathrm{CeO}_{2}$ в биополимерной оболочке из полисахарида мальтодекстрина. Мальтодекстрин представляет собой продукт неполного кислотного или ферментативного гидролиза картофельного или кукурузного крахмала и используется в производстве пищевых добавок, так как является безопасным компонентом. Поэтому этот биополимер представляет интерес для использования в качестве коллоидного стабилизатора золей наночастиц, которые планируется применять в биомедицинской практике. Целью данной работы является исследование морфологии, физико-химических свойств и биологической активности наночастиц оксида церия, стабилизированных мальтодекстрином.

\section{2. Детали эксперимента}

Наночастицы оксида церия $\mathrm{CeO}_{2}$ в мальтодекстриновой оболочке были получены методом осаждения согласно методике, представленной в работах $[12,13]$. В качестве исходных реагентов использовали: раствор нитрата церия (III) $\left(\mathrm{Ce}\left(\mathrm{NO}_{3}\right)_{3} \cdot x \mathrm{H}_{2} \mathrm{O}\right)$, раствор аммиака $\mathrm{NH}_{4} \mathrm{OH}$, мальтодекстрин (МД) с декстрозным эквивалентом 10-12, изопропиловый спирт абсолютный, дистиллированная вода. Все реагенты марки ч.д.а. (массовая доля примесей не более $0.05 \%$ ). Для приготовления исходного раствора производилось растворение мальтодекстрина в дистиллированной воде при комнатной температуре и внесение раствора нитрата церия при соблюдении мольного соотношения компонентов $\mathrm{Ce}: \mathrm{MД}=1: 4$. В качестве осадителя использовался водный раствор аммиака.

Морфологию поверхности и размер частиц синтезированных нанопорошков оксида церия исследовали методом растровой электронной микроскопии (РЭМ) при помощи электронного микроскопа X-Act ADD + JSM-5900LV (Jeol, Япония), оснащенного системой волнодисперсионного микроанализатора, шлюзовой камерой и устройством для подавления электромагнитных помех INCA Energy 250 и INCA Wave 500. Микрофотографии поверхности исследуемого материала получали с использованием детекторов обратнорассеянных электронов (режим BSE) и вторичных электронов (режим SE). В качестве источника электродов использовали W катод, ускоряющее напряжение составляло $10 \mathrm{kV}$.

Для исследования люминесцентно-оптических свойств и антиоксидантной активности были использованы золи наночастиц. Наночастицы диспергировали в дистиллированной воде и обрабатывали ультразвуком. Измерение спектров оптического поглощения проводили с помощью спектрофотометра Helios Alpha $(\lambda=190-1000 \mathrm{~nm})$, оснащенного программным обеспечением Vision 32. Расчет ширины запрещенной зоны нанокристалла производился графическим методом Тауца [14]. Временные зависимости оптической плотности золей наночастиц на определенных длинах волн измеряли при помощи спектрофотометра ПЭ-5400УФ (,ЭКРОСХИМ“汭. Спектры фотолюминесценции (ФЛ) наночастиц $\mathrm{CeO}_{2}$ измеряли с использованием флуоресцентного спектрофотометра Cary Eclipse (Agilent). Спектры ФЛ не корректировали на спектральную чувствительность оптического тракта.

Антиоксидантную активность наночастиц оксида церия оценивали по их способности имитировать поведение ферментов каталазы и пероксидазы, а также возможности инактивировать гидроксильные радикалы. Каталазную миметическую активность наночастиц $\mathrm{CeO}_{2}$ исследовали путем измерения оптической плотности золей наночастиц до и после добавления пероксида водорода $\mathrm{H}_{2} \mathrm{O}_{2}$ [15]. Пероксидазную миметическую активность наночастиц определяли, используя буферный раствор, содержащий $3,3^{\prime}, 5,5^{\prime}$-тетраметилбензидин (ТМБ) и пероксид водорода $\mathrm{H}_{2} \mathrm{O}_{2}$ [16]. Для определения способности исследуемых наночастиц $\mathrm{CeO}_{2}$ ингибировать гидроксильные радикалы было использовано свойство красителя метилового фиолетового (МФ) обесцвечиваться под действием $\mathrm{OH}^{\bullet}$-радикалов [16]. 
a
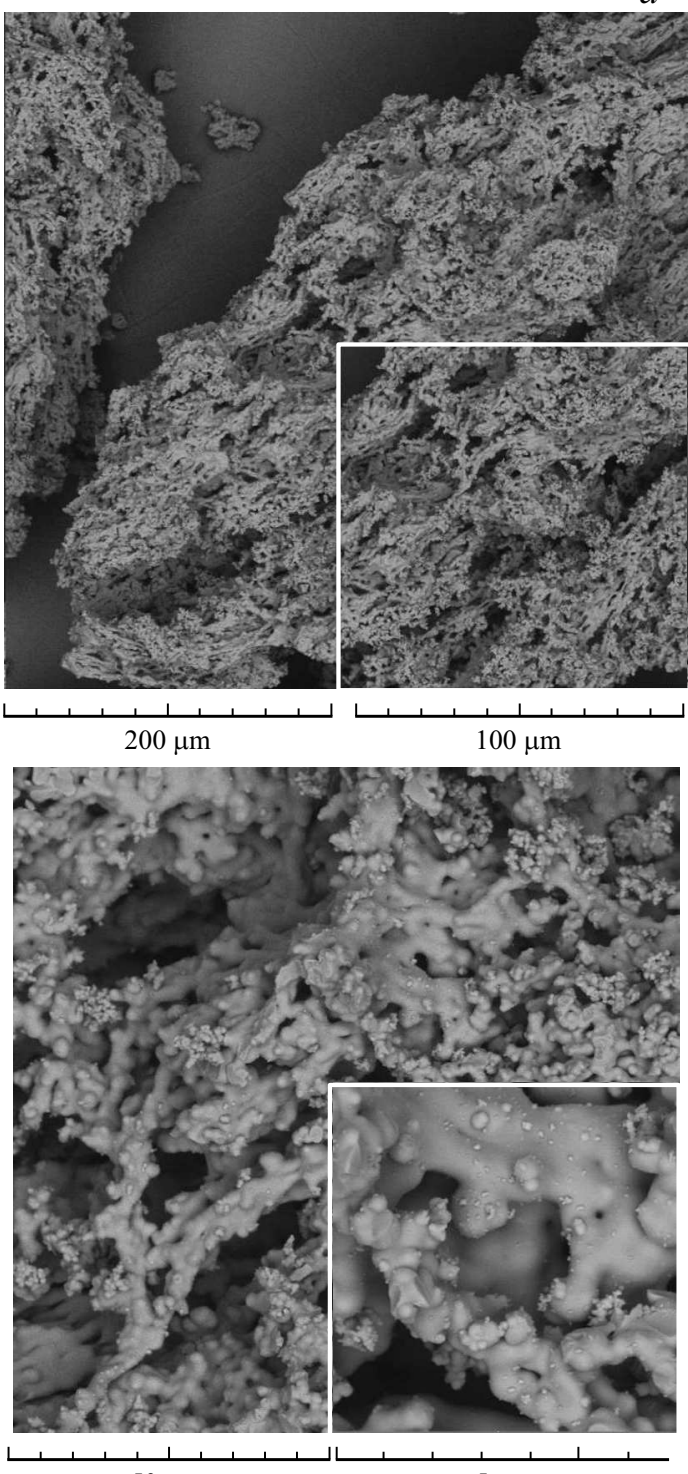

$50 \mu \mathrm{m}$

$5 \mu \mathrm{m}$
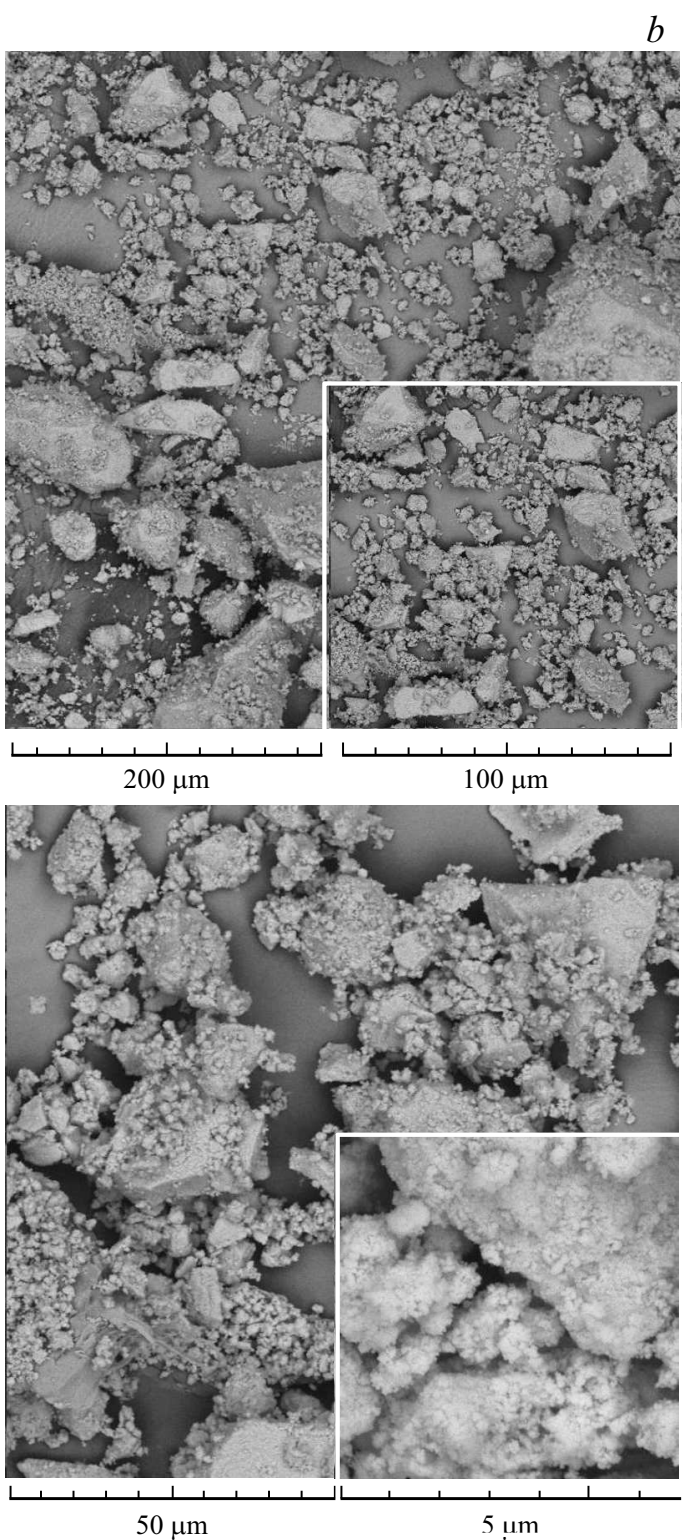

Рис. 1. Электронные РЭМ-микрофотографии наночастиц $\mathrm{CeO}_{2}$, синтезированных с использованием $(a)$ и без использования $(b)$ мальтодекстрина.

\section{3. Результаты эксперимента и их обсуждение}

\section{1. Морфология наночастиц оксида церия, стабилизированных мальтодекстрином}

Структура и свойства поверхности наночастиц являются основными факторами, определяющими их биологическую активность в живых системах. Данные характеристики влияют на заряд поверхности наночастиц, их размеры, агрегативную устойчивость золей, которые обусловливают функциональные свойства наночастиц, а также их возможную токсичность.

На рис. 1 представлены электронные микрофотографии нанопорошка $\mathrm{CeO}_{2}$, синтезированного с использо- ванием $(a)$ и без использования $(b)$ мальтодекстрина, при различном увеличении. Микроскопический анализ показал, что нанопорошок $\mathrm{CeO}_{2}$ состоит из агломератов с размерами порядка нескольких сотен микрометров. Большую часть агломератов составляют полисахариды, входящие в состав мальтодекстрина (декстрин, глюкоза, мальтоза), а ионы церия располагаются на поверхности полисахаридной цепочки. Форма наночастиц близка к сферической. Необходимо учитывать, что мальтодекстрин, используемый при синтезе наночастиц как стабилизатор, может существенно изменять их форму, размер и другие характеристики. Поэтому для исследования его влияния на морфологию поверхности наночастиц были получены микрофотографии нанопорошка $\mathrm{CeO}_{2}$, синтезированного по аналогичной методике, но без 
использования мальтодекстрина. Как видно из рис. $1, b$, наночастицы $\mathrm{CeO}_{2}$ без полисахаридной оболочки имеют размеры порядка десятка нанометров, однако ввиду отсутствия стабилизатора склеиваются и образуют крупные агломераты. Таким образом, полисахарид мальтодекстрин обеспечивает достаточно хорошую агрегативную устойчивость наночастиц.

\section{2. Люминесцентно-оптические свойства золей наночастиц оксида церия, стабилизированных мальтодекстрином}

Использование биополимерных молекул при синтезе наночастиц $\mathrm{CeO}_{2}$ позволяет одновременно контролировать размеры получаемых наночастиц и стабилизировать водные высокодисперсные золи $[11,13]$. Поэтому можно предполагать, что в результате синтеза наночастицы $\mathrm{CeO}_{2}$, стабилизированные мальтодекстрином, будут характеризоваться выраженной кислородной нестехиометрией и, соответственно, наличием дефектов кристаллической решетки. Для наночастиц оксида церия характерно формирование следующих дефектов: кислородные вакансии и связанные с ними $\mathrm{F}^{0}, \mathrm{~F}^{+}$и $\mathrm{F}^{++}$-центры, ионы $\mathrm{Ce}^{3+}$, ассоциированные с наличием кислородных вакансий, комплексы с переносом заряда $\mathrm{Ce}^{4+}-\mathrm{O}^{2-}[17]$. Некоторые дефектные центры обладают оптической активностью и могут быть обнаружены методами оптической спектроскопии.

На рис. 2, а приведены спектры оптического поглощения золей наночастиц оксида церия и мальтодекстрина. Спектр оптического поглощения золя наночастиц $\mathrm{CeO}_{2}$ характеризуется интенсивной полосой поглощения в диапазоне 220-400 nm с максимумом при $\lambda \approx 270 \mathrm{~nm}$. Данная полоса может быть обусловлена фотоиндуцированными оптическими переходами с переносом заряда с $2 p$-орбитали кислорода на незаполненную $4 f$-орбиталь иона $\mathrm{Ce}^{4+}[18]$.

Поскольку исследуемые наночастицы покрыты мальтодекстриновой оболочкой, которая также может поглощать излучение в данном диапазоне длин волн, то важно оценить, какой вклад в полученный спектр вносит мальтодекстрин. Для этого при аналогичных условиях был измерен спектр раствора мальтодекстрина с концентрацией, равной его концентрации в золе наночастиц (рис. 2, $a$, штриховая линия). Видно, что мальтодекстрин практически не поглощает излучение в исследуемом диапазоне длин волн. Данный факт указывает на возможность использования метода оптической спектроскопии для исследования свойств наночастиц и их изменений, возникающих при взаимодействии с активными формами кислорода.

Полученные спектральные данные также могут быть использованы для определения ширины запрещенной зоны нанокристалла $E_{g}$. Для этого согласно методу Тауца спектр оптического поглощения наночастиц $\mathrm{CeO}_{2}$ был перестроен в координатах $(\alpha h v)^{2}$ от $h v$, где $\alpha-$ коэффициент поглощения, $h v-$ энергия кванта света [19].
На рис. 2, $b$ представлены результаты графического определения ширины запрещенной зоны $E_{g}$. Согласно полученным данным, значение ширины запрещенной зоны для прямозонных переходов составило $3.4 \mathrm{eV}$.

На рис. 3 приведен спектр фотолюминесценции (ФЛ) золя наночастиц оксида церия, измеренный при возбуждении $\lambda_{\mathrm{ex}}=250 \mathrm{~nm}$. В видимой области спектр люминесценции представлен широкой неэлементарной полосой ФЛ, простирающейся в диапазоне от 350 до $600 \mathrm{~nm}$, с максимум в области $370 \mathrm{~nm}$. Результаты декомпозиции спектра ФЛ свидетельствуют о наличии двух перекрывающихся основных элементарных полос гауссовой формы. Наблюдаемое излучение при $370 \mathrm{~nm}$, вероятно, связано с излучательными переходами $5 d \rightarrow 4 f$ в ионах $\mathrm{Ce}^{3+}$. Присутствие широкой низкоинтенсивной полосы свечения в области 400-500 nm может быть связано с формированием оптически активных дефектов, ассоциированных с кислородными вакансиями на поверхности наночастиц [18].
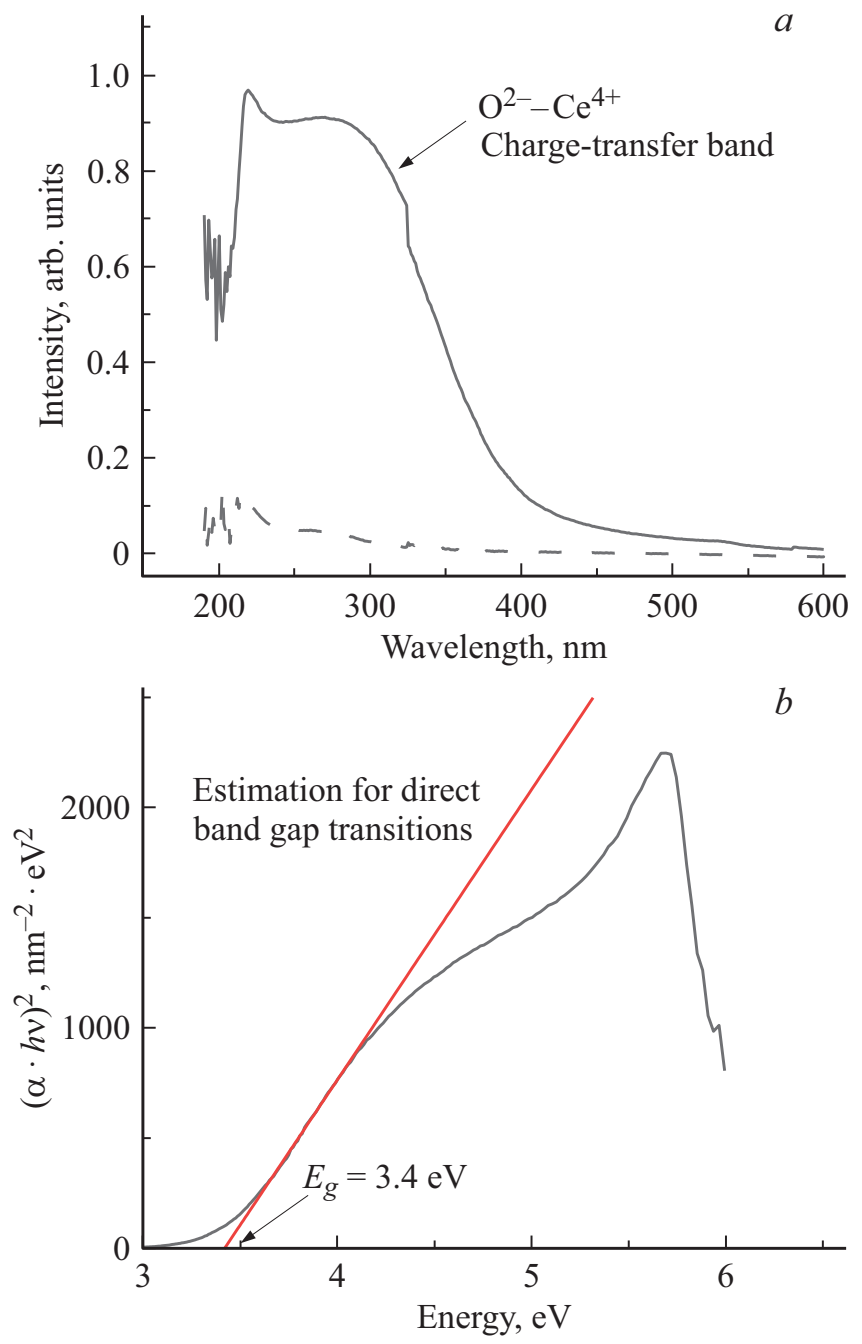

Рис. 2. (a) Спектры оптического поглощения золей наночастиц $\mathrm{CeO}_{2}$ (сплошная линия) и раствора мальтодекстрина (штриховая линия). (b) Оценка ширины запрещенной зоны для прямозонных переходов в наночастицах $\mathrm{CeO}_{2}$. 


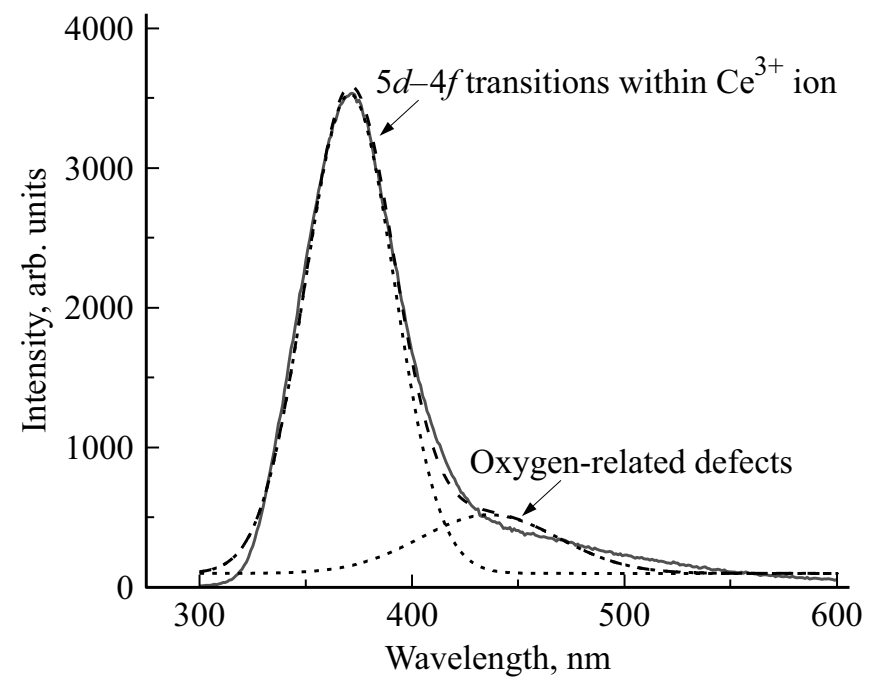

Рис. 3. Спектр фотолюминесценции золя наночастиц $\mathrm{CeO}_{2}$ при возбуждении $\lambda_{\mathrm{ex}}=250 \mathrm{~nm}$. Пунктирными линиями показаны выделенные элементарные полосы гауссовой формы, штриховой линией показана аппроксимирующая кривая.

На основании проведенного анализа можно сделать вывод о малых размерах стабилизированных мальтодекстрином наночастиц $\mathrm{CeO}_{2}$ и, соответственно, их сильной кислородной нестехиометрии. Такая структура обусловливает активность наночастиц оксида церия в окислительно-восстановительных процессах. Так, в частности, наночастицы $\mathrm{CeO}_{2}$ способны связывать реакционные кислородсодержащие соединения и радикалы, губительные для живых систем, т.е. проявлять антиоксидантные свойства.

\section{3. Каталазная миметическая активность наночастиц}

Пероксид водорода $\mathrm{H}_{2} \mathrm{O}_{2}$ является одной из активных форм кислорода и нейтрализуется ферментом каталазой. Для исследования каталазной миметической активности наночастиц $\mathrm{CeO}_{2}$ были проанализированы изменения, происходящие в спектрах их оптического поглощения после взаимодействия с пероксидом водорода (рис. 4, a).

Согласно представленным спектрам, добавление к золю наночастиц $\mathrm{H}_{2} \mathrm{O}_{2}$ приводит к смещению края поглощения в область больших длин волн (рис. 4,a). Известно, что положение полос в спектре оптического поглощения наночастиц $\mathrm{CeO}_{2}$, содержащих смешанные валентные состояния $\mathrm{Ce}^{3+}$ и $\mathrm{Ce}^{4+}$, зависит от величины соотношения $\mathrm{Ce}^{3+} / \mathrm{Ce}^{4+}[20]$, при этом увеличение относительного содержания ионов $\mathrm{Ce}^{3+}$ приводит к смещению полосы поглощения в синюю область [21]. В полученных спектрах, наоборот, наблюдается смещение края поглощения в сторону красного диапазона длин волн. Дополнительным подтверждением изменения валентного соотношения $\mathrm{Ce}^{3+} / \mathrm{Ce}^{4+}$ в сторону увеличения доли ионов $\mathrm{Ce}^{4+}$ в процессах взаимодействия является изменение окраски золя наночастиц от бледнодо ярко-желтой после введения в него пероксида водорода. Появление желтой окраски золя в данном случае может быть обусловлено поглощением ионами $\mathrm{Ce}^{4+}$ излучения в данной области. При этом во время проведения эксперимента изменение окраски золя происходило практически мгновенно после добавления в нее $\mathrm{H}_{2} \mathrm{O}_{2}$ (рис. $4, b$ ), что указывает на быструю скорость процессов взаимодействия наночастиц с данной активной формой кислорода.

Увеличение интенсивности поглощения наночастиц $\mathrm{CeO}_{2}$ после добавления $\mathrm{H}_{2} \mathrm{O}_{2}$ в области $300-450 \mathrm{~nm}$ может быть связано как с ростом количества ионов $\mathrm{Ce}^{4+}$, так и с образованием на поверхности наночастиц адсорбированных форм кислорода (например,
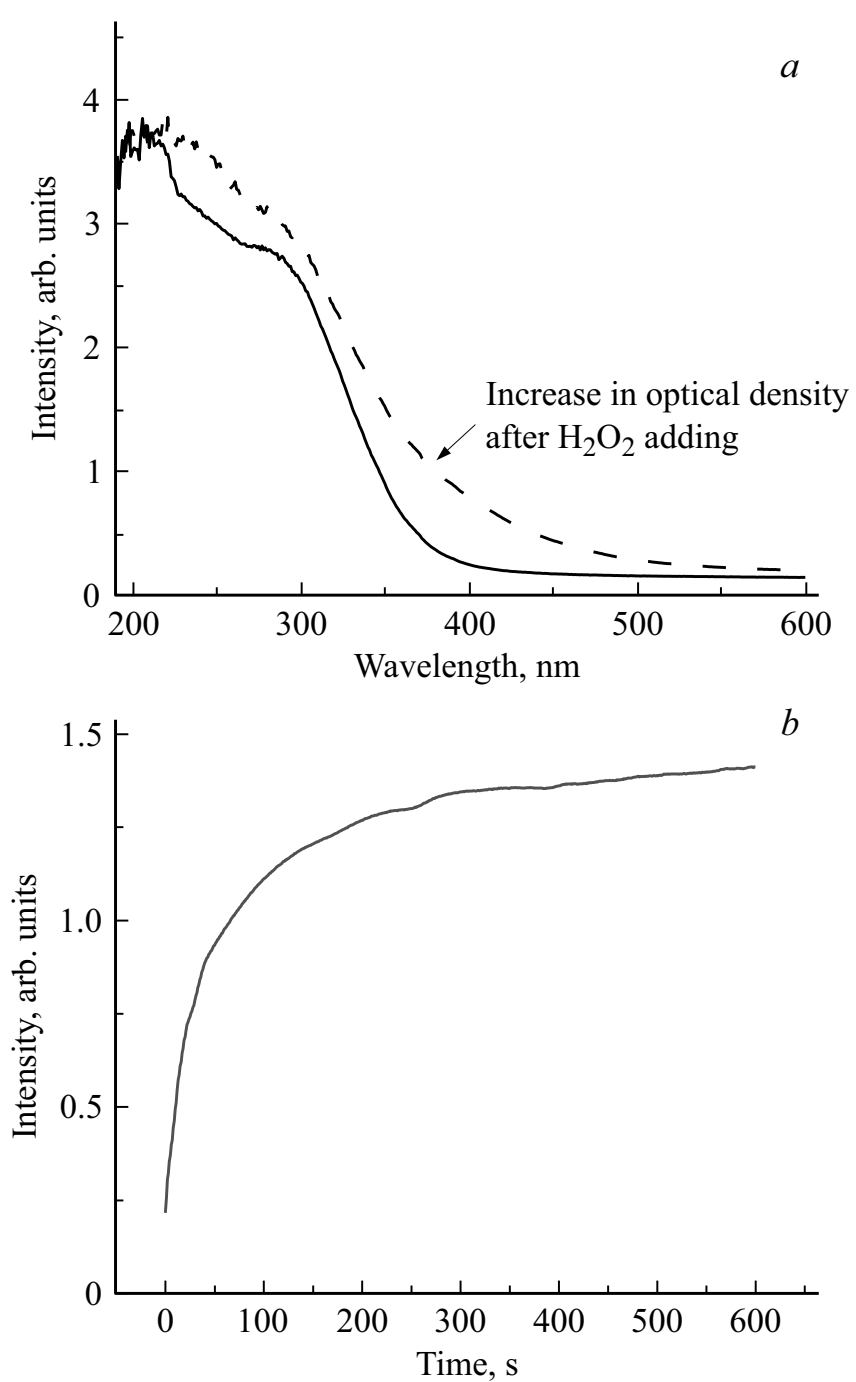

Рис. 4. Исследование каталазной миметической активности золей наночастиц $\mathrm{CeO}_{2}: a-$ спектры оптического поглощения золей наночастиц $\mathrm{CeO}_{2}$ до и после добавления пероксида водорода $\mathrm{H}_{2} \mathrm{O}_{2}$ (сплошная и штриховая линии соответственно); $b$ - временная зависимость оптической плотности золя наночастиц на длине волны $\lambda=400 \mathrm{~nm}$ после добавления пероксида водорода $\mathrm{H}_{2} \mathrm{O}_{2}$. 
гидропероксида), поглощающих излучение в данной области [22]. Нельзя исключать также одновременное протекание этих процессов, при которых образование продуктов окисления сопровождается изменением степени окисления церия.

\section{4. Пероксидазная миметическая активность наночастиц}

В отличие от каталазы, субстратом фермента пероксидазы является не только сам пероксид водорода, но и неорганические или органические молекулы, которые окисляются пероксидом водорода в присутствии
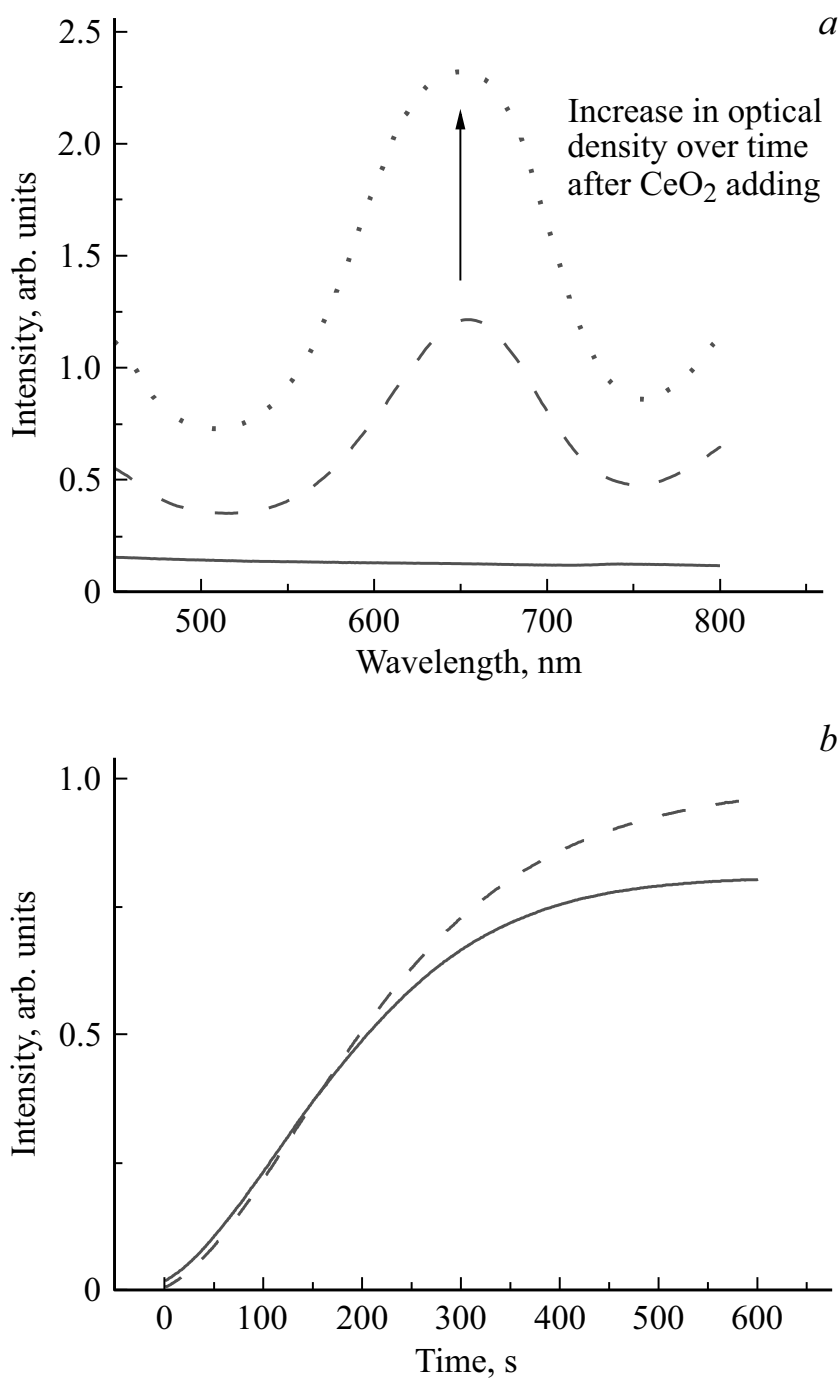

Рис. 5. Исследование пероксидазной миметической активности золей наночастиц $\mathrm{CeO}_{2}: a-$ спектры оптического поглощения раствора ТМБ и пероксида водорода $\mathrm{H}_{2} \mathrm{O}_{2}$ до (сплошная линия) и после добавления золя наночастиц $\mathrm{CeO}_{2}$ (штриховая линия - сразу после добавления $\mathrm{CeO}_{2}$, пунктирная линия через $5 \mathrm{~min}$ после добавления $\left.\mathrm{CeO}_{2}\right) ; b-$ временная зависимость оптической плотности раствора ТМБ и пероксида водорода $\mathrm{H}_{2} \mathrm{O}_{2}$ на длине волны $\lambda=652 \mathrm{~nm}$ после добавления золя наночастиц $\mathrm{CeO}_{2}$ с разными концентрациями $(25 \mu \mathrm{g} / \mathrm{ml}$ и $50 \mu \mathrm{g} / \mathrm{ml}$ - сплошная и штриховая линии соответственно). этого энзима. Таким образом, пероксидаза является окислительно-восстановительным ферментом. Пероксидаза контролирует уровень пероксида водорода, используя его в качестве акцептора электронов при участии в окислении биологических субстратов. Пероксидазу нельзя в полной мере назвать антиоксидантом, однако, согласно работе [23], антиоксиданты и пероксидаза входят в единую систему антиоксидантной защиты и контролируют уровень друг друга.

Для исследования пероксидазной миметической активности наночастиц $\mathrm{CeO}_{2}$ в данном исследовании были проанализированы изменения, происходящие в спектрах раствора 3 , 3', 5, 5'-тетраметилбензидина (ТМБ) после добавления в него пероксида водорода $\mathrm{H}_{2} \mathrm{O}_{2}$ и золя наночастиц $\mathrm{CeO}_{2}$ (рис. 5,a). В процессе реакции, катализируемой пероксидазой, происходит окисление ТМБ в продукт, имеющий синюю окраску и максимум поглощения при $652 \mathrm{~nm}$ (рис. 5, $a$ ). На рис. 5, $b$ представлена временная зависимость оптической плотности раствора ТМБ и пероксида водорода $\mathrm{H}_{2} \mathrm{O}_{2}$ на длине волны $\lambda=652 \mathrm{~nm}$ после добавления золя наночастиц $\mathrm{CeO}_{2}$ с разными концентрациями (25 и $\left.50 \mu \mathrm{g} / \mathrm{ml}\right)$. Видно, что реакция окисления ТМБ в присутствии $\mathrm{H}_{2} \mathrm{O}_{2}$ и наночастиц $\mathrm{CeO}_{2}$ происходит очень быстро в первые минуты, затем стремится к насыщению.

Предполагается, что пероксидазная активность наночастиц $\mathrm{CeO}_{2}$ связана с образованием на их поверхности адсорбированных форм кислорода вследствие взаимодействия с пероксидом водорода. Отмечается, что формирование подобных пероксо- или гидропероксоформ обусловливает окисление ТМБ [16,24]. Таким образом, можно сделать вывод о способности наночастиц $\mathrm{CeO}_{2}$ имитировать поведение фермента пероксидазы.

\section{5. Способность наночастиц инактивировать гидроксильные радикалы}

Среди всех активных форм кислорода наиболее реакционноспособным является гидроксильный радикал. Способность наночастиц $\mathrm{CeO}_{2}$ инактивировать действие данных радикалов была исследована при помощи красителя метилового фиолетового, изменяющего интенсивность своей окраски при реакции с ОН•-радикалами. Для получения $\mathrm{OH}^{\bullet}$-радикалов использовали реакцию Фентона, по которой их образование происходит в биологических системах (при взаимодействии соли двухвалентного железа $\mathrm{FeSO}_{4}$ и пероксида водорода $\mathrm{H}_{2} \mathrm{O}_{2}$ ). На рис. 6, $a$ представлены спектры оптического поглощения раствора красителя метиловый фиолетовый (сплошная линия), а также растворов МФ после добавления сульфата железа $\mathrm{FeSO}_{4}$ и пероксида водорода $\mathrm{H}_{2} \mathrm{O}_{2}$ (штриховая линия) и $\mathrm{FeSO}_{4}, \mathrm{H}_{2} \mathrm{O}_{2}$ и золя наночастиц $\mathrm{CeO}_{2}$ (пунктирная линия). Добавление $\mathrm{FeSO}_{4}$ и $\mathrm{H}_{2} \mathrm{O}_{2}$ к раствору метилового фиолетового приводит к уменьшению интенсивности поглощения в диапазоне 480-620 nm, что связано с образованием в результате реакции Фентона гидроксильных радикалов и обесцвечиванием раствора 

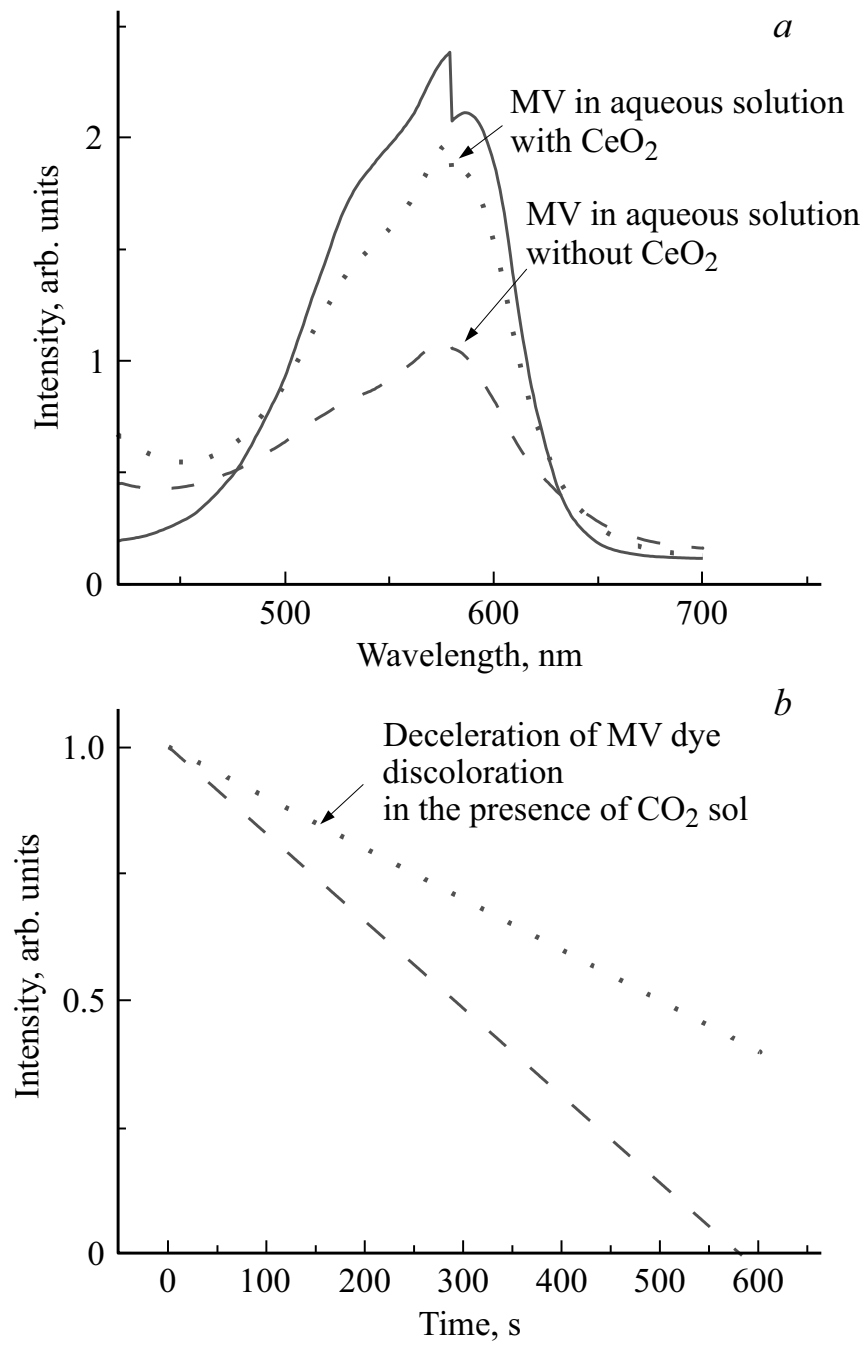

Рис. 6. Исследование способности золей наночастиц $\mathrm{CeO}_{2}$ инактивировать гидроксильные радикалы: $a-$ спектры оптического поглощения раствора красителя МФ (сплошная линия), раствора МФ после добавления $\mathrm{FeSO}_{4}$ и $\mathrm{H}_{2} \mathrm{O}_{2}$ (штриховая линия), раствора МФ после добавления $\mathrm{FeSO}_{4}, \mathrm{H}_{2} \mathrm{O}_{2}$ и золя наночастиц $\mathrm{CeO}_{2}$ (пунктирная линия); $b-$ временная зависимость оптической плотности раствора МФ на длине волны $\lambda=585 \mathrm{~nm}$ после добавления $\mathrm{FeSO}_{4}$ и $\mathrm{H}_{2} \mathrm{O}_{2}$ (штриховая линия) и после добавления $\mathrm{FeSO}_{4}, \mathrm{H}_{2} \mathrm{O}_{2}$ и золя наночастиц $\mathrm{CeO}_{2}$ (пунктирная линия).

красителя под их действием (рис. $6, a$, штриховая линия). Введение золя наночастиц в раствор приводит к снижению степени деградации красителя и более высокому значению оптической плотности раствора при $585 \mathrm{~nm}$ (рис. 6, $a$, пунктирная линия).

На рис. 6, $b$ представлена временная зависимость оптической плотности раствора МФ на длине волны $\lambda=585 \mathrm{~nm}$ после добавления $\mathrm{FeSO}_{4}$ и $\mathrm{H}_{2} \mathrm{O}_{2}$ (штриховая линия) и после добавления $\mathrm{FeSO}_{4}, \mathrm{H}_{2} \mathrm{O}_{2}$ и золя наночастиц $\mathrm{CeO}_{2}$ (пунктирная линия). Видно, что скорость обесцвечивания раствора МФ с $\mathrm{FeSO}_{4}$ и $\mathrm{H}_{2} \mathrm{O}_{2}$ замедляется при добавлении золя наночастиц $\mathrm{CeO}_{2}$.
Следовательно, можно сделать вывод, что наночастицы $\mathrm{CeO}_{2}$ способны поглощать часть $\mathrm{OH}^{\bullet}$-радикалов и тем самым защищать краситель от их действия.

Взаимодействие наночастиц $\mathrm{CeO}_{2}$ с высокореактивным $\mathrm{OH}^{\bullet}$-радикалом происходит за счет переключения между двумя валентными состояниями $\mathrm{Ce}^{3+}$ и $\mathrm{Ce}^{4+}$. Благодаря способности к саморегенерации наночастиц $\mathrm{CeO}_{2}$, данный процесс происходит непрерывно в течение всего времени инкубации. При этом активность наночастиц обусловлена присутствием на их поверхности именно ионов $\mathrm{Ce}^{3+}$, которые выполняют роль активных центров фермента [25].

\section{4. Заключение}

В настоящей работе исследовались наночастицы оксида церия $\mathrm{CeO}_{2}$, полученные методом осаждения и стабилизированные полисахаридной мальтодекстриновой оболочкой во время синтеза. Исследование наночастиц оксидов церия проводилось с использованием методов микроскопического анализа, а также оптической и люминесцентной спектроскопии.

Микроскопический анализ поверхностной структуры стабилизированных мальтодекстрином нанопорошков оксида церия $\mathrm{CeO}_{2}$ показал, что они состоят из агломератов с размерами порядка несколько сотен $\mu \mathrm{m}$, ионы церия располагаются на поверхности полисахаридной цепочки. На основании полученных микрофотографий можно утверждать, что синтезированные наночастицы имеют нанометровые размеры.

Для исследуемого материала обнаружено формирование оптически активных центров, ответственных за оптическое поглощение в УФ-области и наблюдаемую люминесценцию. Данные дефекты, вероятно, имеют природу, связанную с кислородными вакансиями и ассоциированными с ними ионами $\mathrm{Ce}^{3+}$. Кислородная нестехиометрия, связанная с образованием на поверхности частиц ионов $\mathrm{Ce}^{3+}$, вероятно, обусловливает биологическую активность наноматериала.

На основании проведенных исследований можно сделать вывод, что наночастицы $\mathrm{CeO}_{2}$ способны выполнять функции ферментов каталазы и пероксидазы и разрушать пероксид водорода. Кроме того, было продемонстрировано, что наночастицы $\mathrm{CeO}_{2}$ способны инактивировать гидроксильные радикалы аналогично молекулярным антиоксидантам (аскорбиновая кислота, токоферол, метионин и т.д.). Таким образом, проведенные исследования показали принципиальную возможность использования наночастиц оксида церия в медицине, например, в качестве потенциальных антиоксидантов для защиты клеток от активных форм кислорода.

Использование наночастиц оксида церия в качестве экзогенных антиоксидантов для защиты клеток от окислительного стресса требует глубокого понимания механизма их каталитической активности. На сегодняшний день предложены возможные модели реакций, однако 
единой точки зрения мнения на данный вопрос не существует и точный механизм взаимодействия наночастиц $\mathrm{CeO}_{2}$ с активными формами кислорода остается неясным. Требуются дальнейшие исследования взаимосвязей между физико-химическими свойствами и биологической активностью наночастиц оксида церия. Более тщательное изучение этой темы, установление строгих закономерностей и связей позволить реализовать широкий спектр биомедицинских применений нанокристаллического оксида церия.

\section{Благодарности}

Авторы выражают благодарность В.В. Касьяновой за помощь и участие в проведении исследования.

\section{Конфликт интересов}

Авторы заявляют, что у них нет конфликта интересов.

\section{Список литературы}

[1] A. Dhall, W. Self. Antioxidants 7, 8, 97 (2018).

[2] N. Thakur, P. Manna, J. Das. J. Nanobiotechnology 17, 1, 1 (2019).

[3] B. Nelson, M. Johnson, M. Walker, K. Riley, C. Sims. Antioxidants 5, 2, 15 (2016).

[4] N.V. Skorodumova, S.I. Simak, B.I. Lundqvist, I.A. Abrikosov, B. Johansson. Phys. Rev. Lett. 89, 16, 166601 (2002).

[5] А.Б. Щербаков, О.С. Иванова, Н.Я. Спивак, В.В. Козик, В.И. Иванов. Синтез и биомедицинские применения нанодисперсного диоксида церия. Издательский дом Томского гос. ун-та, Томск (2016). $476 \mathrm{c}$.

[6] Z. Lu, Y. Dang, C. Dai, Y. Zhang, P. Zou, H. Du, Y. Zhang, M. Sun, H. Rao, Y. Wang. J. Hazardous Mater. 403, 123979 (2021).

[7] K.R.B. Singh, V. Nayak, T. Sarkar, R.P. Singh. RSC Advances. Royal Soc. Chem. 10, 45, 27194 (2020).

[8] M. Darroudi, M. Ahmad, A. Abdullah, N. Ibrahim. Int. J. Nanomedicine 6, 1, 569 (2011).

[9] A.B. Shcherbakov, N.M. Zholobak, V.K. Ivanov, O.S. Ivanova, A.V. Marchevsky, A.E. Baranchikov, N.Ya. Spivak, Yu.D. Tretyakov. Russ. J. Inorg. Chem. 57, 11, 1411 (2012).

[10] H. Yazici, E. Alpaslan, T.J. Webster. JOM 67, 4, 804 (2015).

[11] F. Charbgoo, M. Bin Ahmad, M. Darroudi. Int. J. Nanomedicine 12, 1401 (2017).

[12] E.O. Baksheev, M.O. Pronina, M.A. Mashkovtsev, A.V. Myshkina, I.N. Bazhukova, V.V. Kasianova. AIP Conf. Proc. 2174, 020156 (2019).

[13] А.Б. Щербаков, Н.М. Жолобак, В.К. Иванов, О.С. Иванова, А.В. Марчевский, А.Е. Баранчиков, Н.Я. Спивак, Ю.Д. Третьяков. Журн. неорган. химии 57, 11, 1499 (2012).

[14] J. Tauc. BMC Public Health 3, 1, 37 (1968).

[15] I. Bazhukova, I. Zvonareva, A. Myshkina, S. Bazhukov, I. Gavrilov, V. Meschaninov. NANOCON 2019 - Conference Proceedings. 11th Int. Conf. Nanomaterials. Res. Appl. 348 (2020).

[16] G. Vinothkumar, P. Arunkumar, A. Mahesh, A. Dhayalan, K. Suresh Babu. New J. Chem. Royal Soc. Chem. 42, 23, 18810 (2018).
[17] E.N. Okrushko, V.V. Seminko, P.O. Maksimuchuk, I.I. Bespalova, N.V. Kononets, O.G. Viagin, Yu.V. Malyukin. Low Temp. Phys. 43, 5, 636 (2017).

[18] A.I. Medalia, B.J. Byrne. Rev. Anal. Chem. 23, 3, 453 (1951).

[19] И.Н. Бажукова, А.В. Мышкина, С.Ю. Соковнин, В.Г. Ильвес, А.Н. Киряков, С.И. Бажуков, Р.А. Вазиров, В.В. Касьянова, И.А. Звонарева. ФТТ 61, 5, 974 (2019).

[20] D. Damatov, J.M. Mayer. Chem. Commun. Royal Soc. Chem. 52, 67, 10281 (2016).

[21] S. Tsunekawa, T. Fukuda, A. Kasuya. J. Appl. Phys. 87, 3, 1318 (2000).

[22] A.L. Popov, A.B. Shcherbakov, N.M. Zholobak, A.Ye. Baranchikov, V.K. Ivanov. Nanosyst. Phys. Chem. Math. 8, 6, 760 (2017).

[23] В.В. Верхотуров. Исследовано в России 4, 605 (2001).

[24] V. Baldim, F. Bedioui, N. Mignet, I. Margaill, J.F. Berret. Nanoscale 10, 15, 6971 (2018).

[25] Y. Xue, Q. Luan, D. Yang, X. Yao, K. Zhou. J. Phys. Chem. 115, 11, 4433 (2011).

Редактор Д.В. Жуманов 